\title{
Brand Equity Dimensions of Mediation in Satisfaction as Customer Loyalty
}

\author{
Anisatul Fauziah ${ }^{1}$, Jesi Irwanto ${ }^{2}$ \\ Departement of Management, STIE Widya Gama Lumajang ${ }^{12}$ \\ Email: anisatulfauziah3@gmail.com
}

https://doi.org/10.30741/wiga.v10i1.518

A R T I C L E I N F O

Date of entry:

02 February 2020

Revision Date:

1 Maret 2020

Date Received:

25 March 2020

\begin{abstract}
A B S T R A C T
Brand equity Strong will deliver value, both for customers and the company. Brand equity can be reflected in the way consumers think, feel, and act in the relationship by brand, price, market share, and profitability of a given brand for the company. This study aimed to examine the effect of the dimensions of brand equity consisting of brand awareness, brand association and perception of significantquality partially and simultaneously on customer satisfaction and customer loyalty. Examine the effect of satisfaction on loyalty and satisfaction as mediator test the influence of the dimensions of brand equity consisting of brand awareness, brand association and a significant perceived quality on customer loyalty superior products glorious in Lumajang banana chips. Respondents in this study were Lumajang community and consumers totalling 200 respondents. With Sobel path analysis and testing of the obtained results of the research test brand awareness, brand association and perceived quality simultaneously significant effect on satisfaction, brand awareness while partial no effect on satisfaction. Simultaneously and partially brand awareness, brand association and perceived quality have a significant effect on loyalty. Satisfaction significant effect on loyalty and satisfaction may be a mediator on the effect of brand awareness, brand association and perception of significant quality on loyalty. Limitations of this study only examined the consumer from Lumajang community, so expected this limitation bias was investigated in future studies.
\end{abstract}

Keywords: Brand Equity, Satisfaction, Loyalty.

\section{INTRODUCTION}

Indonesia is a country with fertile land capable of producing a variety of crops seeded in their respective areas. Tourism programs are constantly encouraged to develop uplifting each region to explore the potential of each, both in producing excellent products, excellent art and featured travel. The products produced in each area is different depending on the type and level of fertility, respectively. One of them is located in Lumajang Regency East Java Province, is located at the foot of Mount Semeru make Lumajang has fertile soil. The fertility of the soil is capable of 
producing a unique plant that is the great banana which can only grow perfectly in the Senduro in Lumajang. The uniqueness of this great banana which was not found in other areas makes this superior banana product. This great banana many processed into chips and banana chips currently glorious is the flagship product in Lumajang. With so many different types of banana chips on the market, it is important to establish that the consumer image of the great banana chips different from other chips products.

The brand is the company's assets are used to distinguish one product from the manufacturer to the other manufacturers-brand as a tool that customers can use to give you the freedom to make choices. The Company is considered to build a strong brand in the minds of consumers if the company has a marketing strategy at the right segmentation. "Brand is a product or service whose dimensions differentiate the goods or services in some way from other products or services that are designed to satisfy the same needs" (Kotler and Keller, 2009: 259). Brands owned by the company will be stronger if it has brand equity (brand equity) is strong. Strong brand equity will provide value, both for customers and the company. Brand equity can be reflected in the way consumers think, feel, and acting in the relationship by brand, price, market share, and profitability of a given brand for the company. According to Kotler and Keller (2009: 263) states that "brand equity is the added value given to products or services offered to consumers in order to create a strong brand association, fun and unique way for customers". Dimensions brand equity can be grouped into four dimensions: brand awareness (brand awareness), perceived quality (perceived quality), brand associations (brand association), brand loyalty (brand loyalty) (Aaker, 1991 in Tjiptono, 2005: 40). "Brand equity is the added value given to products or services offered to consumers in order to create a strong brand association, fun and unique way for customers". Dimensions brand equity can be grouped into four dimensions: brand awareness (brand awareness), perceived quality (perceived quality), brand associations (brand association), brand loyalty (brand loyalty) (Aaker, 1991 in Tjiptono, 2005: 40). "Brand equity is the added value given to products or services offered to consumers in order to create a strong brand association, fun and unique way for customers". Dimensions brand equity can be grouped into four dimensions: brand awareness (brand awareness), perceived quality (perceived quality), brand associations (brand association), brand loyalty (brand loyalty) (Aaker, 1991 in Tjiptono, 2005: 40).

Consumers will be able to recall the brand if the brand can deliver greater value to him, perception of quality provided by an increasingly strong brand formed along with increasing consumer experience. The satisfaction that is felt towards the brand will make customers loyal to the brand. Based on the experience perceived by consumers that will arise consumer confidence so that there are no doubt consumers in making purchasing decisions. Based on this phenomenon, the researchers are interested in testing the ability of the great banana chips in Lumajang in building customer loyalty by first providing the satisfaction of the product. Brand Equity is a set of assets and liabilities (liabilities) brand-related to with a brand, names and symbols which increase or decrease the value of a given product or service to the company or the company's customers ". (Aaker, 1991 in Tjiptono, 2005: 39), describes the brand equity into four dimensions, namely Brand Awareness (Brand Awareness), Trademark Association (Brand Associations), Perceived Quality (Perceived Quality). Brand awareness is the ability of potential customers to recognize or remember that a brand belonging to the particular product category (Aaker, 1991 in Kertajaya 2010: 64). The brand association is everything plugged in memory customers about a brand (Aaker, 1991 in Kertajaya 2010: 66). describes brand equity into four dimensions, namely Brand Awareness (Brand Awareness), Trademark Association (Brand Associations), Perceived Quality (Perceived Quality). Brand awareness is the ability of potential customers to recognize or remember that a brand belonging to the particular product category (Aaker, 1991 in Kertajaya 2010: 64). The brand association is everything plugged in memory customers about a brand (Aaker, 1991 in Kertajaya 2010: 66). describes brand equity into four dimensions, namely Brand Awareness (Brand Awareness), Trademark Association (Brand Associations), Perceived Quality (Perceived Quality). Brand awareness is the ability of potential customers to recognize or remember that a brand belonging to the particular product category (Aaker, 1991 in Kertajaya 
2010: 64). The brand association is everything plugged in memory customers about a brand (Aaker, 1991 in Kertajaya 2010: 66).

Perception of quality is customer perception of quality or excellence of a product or service in connection with the desired goal "(Aaker, 1991 in Kartajaya 2010: 73). Satisfaction is feeling happy or disappointed someone who emerged after comparing the perception/impression of the performance of a product and hopes "(Sunarto, 2006: 17). Customer loyalty is the tendency of a customer to select a value above the organization offered an alternative bid competitor organization (Sofyan, 2013: 14). The purpose of this study was to obtain evidence of the influence of variable partially and simultaneously to customer satisfaction and obtaining of evidence that can be mediator satisfaction for the influence of the dimensions of brand equity consisting of brand awareness,

On the formulation and purpose of this study, the hypothesis to be tested as follows: H1: Suspected dimensions of brand equity consisting of brand awareness, brand association and perception of quality has a significant influence partially towards customer satisfaction. H2: Suspected dimensions of brand equity consisting of brand awareness, brand association and perception of quality has a significant influence on customer satisfaction simultaneously. H3: Suspected dimensions of brand equity consisting of brand awareness, brand association and perception of quality has a significant influence partially on customer loyalty. H4: Suspected dimensions of brand equity consisting of brand awareness, brand association and perception of quality has a significant influence on customer loyalty simultaneously. H5: Anticipated customer satisfaction has a significant influence on customer loyalty. H6: Suspected of satisfaction can be the mediator to influence the dimensions of brand equity consisting of brand awareness, brand association and perceived quality on customer loyalty

\section{RESEARCH METHODS}

This research is survey research (survey research) is research that does not make any changes, or no special treatment of the variables studied (non-experimental). The purpose of this research is explanatory (explanatory research) where the explanatory study is a type of research that explains the causal relationship between one variable to another variable through hypothesis testing. By its nature, this research is explorative for further testing on research is required then the study is explorative. This study was conducted to Lumajang community which is also a product of superior customer supreme Lumajang banana chips.

According to the source, the acquired data to be analyzed in this study is the external data is data obtained from the outside, whereas the data type is primarily because the data collected researchers themselves of respondents directly the primary data in the form of respondents' answers on questionnaires distributed to respondents about brand equity and the effect on customer satisfaction and loyalty majestic in Lumajang banana chips. The population in this study is the whole community that is Lumajang customers superior products glorious Lumajang banana chips. The method of determining the sample size used is a method developed by Roscoe in his book Research Methods for Business (1982: 253) as cited in (Sugiyono, 2009: 129), that is, when the research will perform multivariate analysis with the number of sample members at least 10 (ten) times the number of variables studied, including the number of independent and dependent variables. The analysis used in this study is a multivariate analysis that multiple regression analysis and path analysis, which consists of 5 (five) variables. Researchers will take a large sample size to capture the opinions of respondents that each variable is represented by $40 \times 5$ variable $=200$ samples. The analysis used in this study is a multivariate analysis that multiple regression analysis and path analysis, which consists of 5 (five) variables. Researchers will take a large sample size to capture the opinions of respondents that each variable is represented by 40 x 5 variable $=200$ samples. The analysis used in this study is a multivariate analysis that multiple regression analysis 
and path analysis, which consists of 5 (five) variables. Researchers will take a large sample size to capture the opinions of respondents that each variable is represented by 40 x 5 variable $=200$ samples.

Data analysis techniques in this study will be done by using path analysis models with IBM SPSS 24. Previous applications will be tested research instruments for the research instrument used a questionnaire that should be tested for validity and reliability. Furthermore, multiple linear regression to go through the test the classical assumption of the normal distribution of data should be free, and free multicollinearity of heteroscedasticity. Path analysis is a technique for analyzing the causal relationships that occur in multiple regression if independent variables affect the dependent variable not only directly but also indirectly-Robert D. Retherford (1993) in Danang Sunyoto (2012: 1).

This study analyzed using two paths to the stages of completion of the analysis as follows: a) Determining the path diagram model-based paradigm of relationship variables. b) Determining the research hypothesis. c) Processing of data with SPSS for substructure 1. d) Processing of data with SPSS for substructure 2. e) Analyzing the regression output. f) Test the accuracy of the resulting model. g) Determine the equation model regression analysis to two lanes.

Effect of mediation on the path analysis was tested using the Sobel test by using the following formula: $S p 2 p 3=\sqrt{p 3^{2} S p 2^{2}+p 2^{2} S p 3^{2}+S p 2^{2} S p 3^{2}} \mathrm{t}=\mathrm{P} 2 \mathrm{P} 3$ / Sp2p3. The criteria for the test as follows: If $\mathrm{t}>\mathrm{t}$ table, then there is the influence of mediation, if $\mathrm{t}<\mathrm{t}$ table, then there is no influence of mediation

(Imam Ghozali, 2013: 255). In this research, testing direct and indirect testing of the dependent variable.

Determine the confidence level (coefficient of confidence) is the amount of confidence the researcher on the research results, while the level of fault tolerance $(\alpha)$ is the magnitude of the margin of error that can be tolerated statistically true, it means that if more than the initial statement will be rejected. With a certain confidence level than the specified value table for $t$, i.e. $t$ $(\alpha) / 2$; df ( $n-2)$. The criteria for the test as follows: Ho accepted if $t$ table $\leq t \leq+t$ table. Ho is rejected if $\mathrm{t}<\mathrm{t}$ table or $\mathrm{t}$ count $>\mathrm{t}$ table

Testing criteria is not directly used for this hypothesis is H0: There is a significant difference between variables. H1: There is a significant influence between variables. Determine the confidence level (coefficient of confidence) is the amount of confidence the researcher on the research results, while the level of fault tolerance $(\alpha)$ is the magnitude of the margin of error that can be tolerated statistically true, it means that if more than the initial statement will be rejected. The value of $\mathrm{F}$ table sought to determine the degree of freedom (df) numerator (numerator) and denominator $\mathrm{df}$ (denominator). Numerator $=$ number of independent variables and denominator $=$ $\mathrm{Nm}-1$, then $\mathrm{F}$ table $=\mathrm{F} \alpha$; df (numerator); denominator. The criteria for the test as follows: Ho accepted if Fhitung $\leq \mathrm{F}$ table. Ho is rejected if $\mathrm{F}$ arithmetic $>$

\section{RESULTS AND DISCUSSION}

Respondents in this study are that people have become consumers Lumajang banana chips grand flagship product. The number of respondents who used the study sample was 200 people. Here are the data that will be presented relating to the general description of the respondents: 
Table 2. Description of Respondents by Gender

\begin{tabular}{clcc}
\hline No. & \multicolumn{1}{c}{ Gender } & Amount & $\%$ \\
\hline 1. & Male & 95 & $47.5 \%$ \\
2. & Woman & 105 & $52.5 \%$ \\
& Amount & 200 & $100 \%$ \\
\hline
\end{tabular}

Source: Results of Questionnaire Research, 2019.

Table 2 shows that of the 200 respondents were selected, indicating that consumers are supreme in Lumajang banana chips dominated the respondents were female, namely by $52.5 \%$.

Table 3. Description of Respondents by Age

\begin{tabular}{crcc}
\hline No. & \multicolumn{1}{c}{ Age } & Amount & \% \\
\hline 1. & 17-25 years & 78 & $39.0 \%$ \\
2. & 26-33 years & 32 & $16.0 \%$ \\
3. & 34-41 years & 24 & $12.0 \%$ \\
4. & 42-49 years & 32 & $16.0 \%$ \\
5. & 50 years and over & 34 & $17.0 \%$ \\
& Amount & 120 & $100 \%$ \\
\hline
\end{tabular}

Source: Results of Questionnaire Research, 2019.

Table 3 shows that of the 200 respondents were selected, indicating that consumers are supreme in Lumajang banana chips is dominated respondents aged 17 to 25 years.

Table 4. Description of Respondents by Education

\begin{tabular}{clcc}
\hline No. & Education & Amount & $\%$ \\
\hline 1. & SD & 29 & $14.5 \%$ \\
2. & SMP & 16 & $8.0 \%$ \\
3. & High School & 78 & $39.0 \%$ \\
4. & BACHELOR & 77 & $38.5 \%$ \\
& Amount & 200 & $100 \%$ \\
\hline
\end{tabular}

Source: Results of Questionnaire Research, 2019.

Table 4 shows that of the 200 respondents were selected, indicating that consumers are supreme in Lumajang banana chips is dominated respondents with a high school education level that is equal to $38.5 \%$.

Table 5. Description of Respondents by Job

\begin{tabular}{clcc}
\hline No. & \multicolumn{1}{c}{ Profession } & Amount & \% \\
\hline 1. & Entrepreneur & 40 & $20.0 \%$ \\
2. & General Employees & 27 & $13.5 \%$ \\
3. & Housewife & 41 & $20.5 \%$ \\
4. & Student / Student & 68 & $34.0 \%$ \\
5. & Pns & 17 & $8.5 \%$ \\
6. & More & 7 & $3.5 \%$ \\
& Amount & 200 & $100 \%$ \\
\hline
\end{tabular}

Source: Results of Questionnaire Research, 2019.

The above data shows that of the 200 respondents were selected, indicating that consumers are supreme in Lumajang banana chips is dominated respondents from among students and students that is equal to $34 \%$.

Results of testing the validity of the questionnaire on 5 (five) variables in this study indicate that all of the items on each statement has a variable count $r>0.3$ with a significant level below $5 \%$, it 
can be concluded that all the questionnaires used to collect data is valid so that it can collect data or information required. Results of testing the reliability of the questionnaire on 5 (five) variables in this study indicate that all items on the statement of each variable have a valueCronbach's Alpha over 0.6, which means reliable. So we can conclude all the concept of measuring each of the variables of the questionnaire used in this study is a reliable questionnaire.

Results of testing the normality of the data showed a normal graph pattern on two models of the satisfaction variables $(\mathrm{Z})$, and to the loyalty variable $(\mathrm{Y})$ where the dots are not far from the diagonal line, this means that the two regression model is already normal distribution. The test results showed that all of the variables used as predictors of the regression model showed VIF were quite small, all of which are under ten and more than 0.1 tolerance value. This means that the independent variables used in the study did not show any symptoms of multicollinearity, which means that all independent variables in this study are mutually independent variables. The test results showed no clear heteroscedasticity pattern of the dots.

Testing of substructures first test multiple linear regression between brand awareness (X1), brand association (X2) and perceived quality (X3) to customer satisfaction (Z1) gives the results of a mathematical model that uses the Standardized Coefficients as follows: $\mathrm{Z} 1=0.070 \mathrm{X} 1+0.204 \mathrm{X} 2$ $+0,526+0,532 \times 3$

While simultaneously obtained the following results: 1) Effect of Brand Equity dimensional independent variable $(\mathrm{X})$ to the satisfaction of $(\mathrm{Z})$ indicated by the calculated $\mathrm{F}$ value $(56.518)>\mathrm{F}$ table (2.65) with a significance level of 0.00 means that there are significant dimension brand Equity significant simultaneously to satisfaction. 2) The value of R square (R2) of 0.468 shows that satisfaction is influenced by the dimensions of brand equity by $46.8 \%$ while the rest indicated by the value of $€ 1$ amounted to $53.2 \%$ shows that satisfaction is influenced by variables the other. 3 ) to determine whether the model regression is right or not, it is necessary to test the hypothesis by using the $\mathrm{F}$ test or by comparing the magnitude of the significant level of the ANOVA table. If the significance of arithmetic $>0.05$, the regression model is said to be not feasible. If the significance count $<0.05$, then the regression model is said to be not feasible. Based on the calculation of the numbers of the significance of $0.00<0.05$, then the regression model obtained from this first substructure testing is feasible and correct.

Testing substructures second test multiple linear regression between brand awareness (X1), brand association (X2), perceived quality (X3) and customer satisfaction (Z1) on customer loyalty (Y1) gives the results of a mathematical model that uses the Standardized Coefficients as follows: $\mathrm{Y} 2=$ $0,155 \mathrm{X} 1+0,095 \mathrm{X} 2+0,304 \mathrm{X} 3+0,302 \mathrm{Z} 1+0.524$ to determine whether the regression model is correct or not, it is necessary to test the hypothesis by using the $\mathrm{F}$ test or by comparing the magnitude of the significant level of the ANOVA table. If the significance of arithmetic $>0.05$, the regression model is said to be not feasible. If the significance count $<0.05$, then the regression model is said to be not feasible. Based on the calculation of the numbers of the significance of 0.00 $<0.05$, then the regression model obtained from this second substructure testing is feasible and correct.

Testing the hypothesis 1 first determined value of t table, where the value t table with $\alpha=5 \%$, df $(n-2)$ obtained t table $(\alpha / 2 ; 200-2)=(0.025 ; 198)= \pm 1.972$. Testing the hypothesis partially or individual for each variable through the first substructure model testing as follows: a) The effect of brand awareness (X1) to the satisfaction of (Z1). Obtained t value of 1.142 with a significant rate of 0.255 means that $t(1.142)$ located between - $t$ table (-1.972) and $t$ table (1.972) and sig (0.255)> $\alpha(0.05)$ then the hypothesis is rejected and it was concluded brand awareness ( X1) had no significant effect on satisfaction (Z). b) The effect of brand association (X2) to the satisfaction of (Z1). Obtained t value of 3.129 with a significant rate of 0.002 means that $t(3.129)>t$ table $(1.972)$ with $\operatorname{sig}(0.002)<\alpha(0,05)$ then the hypothesis is accepted and concluded brand association (X2) significant effect on satisfaction (Z1). c) The effect of perceived quality (X3) to the 
satisfaction of (Z1). Obtained t value of 8.726 with a significant level of 0.000 means that $t$ (8.726)> t table (1.972) and sig $(0.000)<\alpha(0.05)$ then the hypothesis is accepted and concluded perceived quality (X3) significantly affects satisfaction (Z1 ).

Testing the hypothesis 2 first determined Ftable value, where the value of F table with ( $\alpha$ ); (DF1); $(\mathrm{DF} 2)=(\alpha 0.05) ;(\mathrm{DF} 1=3) ;(\mathrm{DF} 2=200-3-1=186)$ were obtained F table $=2.65$. From the test results obtained calculated $\mathrm{F}$ value of 57.518 with a significant level of 0.000 means that $\mathrm{F}$ count $(57.518)>\mathrm{F}$ table $(2.65)$ and $\mathrm{sig}(0.000)<\alpha(0.05)$ then the hypothesis is accepted and concluded there are significant dimensions of brand equity consists of brand awareness, brand association and perception simultaneously significant quality to customer satisfaction.

Testing the hypothesis 3 first determined value of t table, where the value t table with $\alpha=5 \%$, df $(n-2)$ obtained t table $(\alpha / 2 ; 200-2)=(0.025 ; 198)= \pm 1.972$. Testing the hypothesis partially or individual for each variable through the second substructure model testing as follows: a) The effect of brand awareness (X1) loyalty (Y1). Obtained t value of 2.780 with a significant level of 0.006 means that $\mathrm{t}(2.780)>\mathrm{t}$ table $(1.972)$ with sig $(0.006)<\alpha(0.05)$ then the hypothesis is accepted and concluded brand awareness (X1) significantly affects customer loyalty (Y ). b) The effect of brand association (X2) to the satisfaction of $(\mathrm{Z} 1)$. Obtained t value of 2.308 with a significant rate of 0.022 means that $t(3.129)>t$ table $(1.972)$ with sig $(0.002)<\alpha(0,05)$ then the hypothesis is accepted and concluded brand association (X2) significantly affects customer loyalty (Y). c) The effect of perceived quality (X3) to the satisfaction of (Z1). Obtained t value of 7.409 with a significant level of 0.000 means that $t(7.409)>t$ table (1.972) and sig $(0.000)<\alpha(0.05)$ then the hypothesis is accepted and concluded perceived quality (X3) significantly affects customer loyalty ( Y).

Testing the hypothesis 4 Ftabel first determined value, where the value of F table with ( $\alpha$ ); (DF1); $(\mathrm{DF} 2)=(\alpha 0.05) ;(\mathrm{DF} 1=3) ;(\mathrm{DF} 2=200-3-1=186)$ were obtained F table $=2.65$. From the test results obtained calculated $\mathrm{F}$ value of 48.743 with a significant level of 0.000 means that $\mathrm{F}$ count $(48.743)>\mathrm{F}$ table $(2.65)$ and $\operatorname{sig}(0.000)<\alpha(0.05)$ then the hypothesis is accepted and concluded there are significant dimensions of brand equity consists of brand awareness, brand association and perception of significant-quality simultaneously on customer loyalty.

Hypothesis testing 5 first determined value of t table, where the value $\mathrm{t}$ table with $\alpha=5 \%$, df (n-2) obtained t table $(\alpha / 2 ; 200-2)=(0.025 ; 198)= \pm 1.972$. Testing the hypothesis partially or individuals to variable customer satisfaction through the second substructure model test obtained $t$ value of 4.250 with a significant level of 0.000 means that $t(4.250)>t$ table (1.972) with sig $(0,000)<\alpha(0.05)$ hypothesis accepted and concluded customer satisfaction (Z1) have a significant effect on customer loyalty (Y).

Testing the hypothesis 6 to test the effect of satisfaction variables as pemediasi between the influence of the dimensions of brand equity consisting of brand awareness, brand association and perceived quality on customer loyalty in the path analysis were tested using Sobel Sobel test by using the formula. The criteria for the test as follows: If $t>t$ table, then there is the influence of mediation. If $\mathrm{t}<\mathrm{t}$ table, then there is no influence of mediation (Imam Ghozali, 2013: 255).

Satisfaction as pemediasi effect of brand awareness against customer loyalty. First determined the value of $\mathrm{t}$ table, where the value $\mathrm{t}$ table with $\alpha=5 \%$, df (n-2) obtained t table $(\alpha / 2 ; 200-2)=$ $(0.025 ; 198)= \pm 1.972$. Therefore the value of $t=2.2745$ is greater than $t$ table at a significance level of 0.05 which means $1,972(2.2745>1.972)$ the satisfaction $(\mathrm{Z} 1)$ proved to be pemediasi between brand awareness (X1) with customer loyalty (Y1) or there is a mediating influence between the satisfaction of brand awareness (X1) with customer loyalty (Y1).

Satisfaction as pemediasi effect against trademark association customer loyalty. First determined the value of t table, where the value t table with $\alpha=5 \%$, df $(n-2)$ obtained table $(\alpha / 2 ; 200-2)=$ 
$(0.025 ; 198)= \pm 1.972$. Therefore the value of $t=1.98491$ greater than $t$ table at a significance level of 0.05 which means $1,972(1.198491>1.972)$ the satisfaction $(Z 1)$ proved to be pemediasi between brand association (X2) and customer loyalty (Y1) or there is a satisfaction mediating influence between the brand associations (X1) with customer loyalty (Y1).

As pemediasi influence satisfaction quality perception against customer loyalty. First determined the value of table, where the value $\mathrm{t}$ table with $\alpha=5 \%$, $\mathrm{df}(\mathrm{n}-2)$ obtained table $(\alpha / 2 ; 200-2)=$ $(0.025 ; 198)= \pm 1.972$. Therefore the value of $t=3.660988$ is greater than $t$ table at a significance level of 0.05 which means $1,972(3.660988>1.972)$ the satisfaction $(\mathrm{Z} 1)$ proved to be pemediasi between perceived quality (X1) with customer loyalty (Y1) or there is a mediating influence between perceived quality satisfaction (X1) with customer loyalty (Y1).

Table 6. Results of Direct Impact Test (Direct Effect)

\begin{tabular}{cllll}
\hline No. & \multicolumn{1}{c}{$\begin{array}{c}\text { Influence } \\
\text { Variables }\end{array}$} & Against Variable & The Symbol & $\begin{array}{c}\text { The Amount } \\
\text { Of Influence }\end{array}$ \\
\hline 1. & Brand Awareness (X1) & Satisfaction (Z1) & b1Z1X1 & .070 \\
2. & Trademark Association (X2) & Satisfaction (Z1) & b2Z1X2 & 0.204 \\
3. & Perception of Quality (X3) & Satisfaction (Z1) & b3Z1X3 & 0,526 \\
4. & Brand Awareness (X1) & Loyalty (Y1) & b4Y1X1 & 0.155 \\
5. & Trademark Association (X2) & Loyalty (Y1) & b5Y1X2 & 0.095 \\
6. & Perception of Quality (X3) & Loyalty (Y1) & b6Y1X3 & 0.304 \\
7. & Satisfaction (Z1) & Loyalty (Y1) & b1Y1Z1 & 0,302 \\
\hline
\end{tabular}

Source: Questionnaire Results Data Processing with SPSS, 2019

Table 7. Test Results Indirect Influence (Indirect Effect)

\begin{tabular}{|c|c|c|c|c|c|}
\hline No. & $\begin{array}{l}\text { Variables } \\
\text { Influence }\end{array}$ & $\begin{array}{l}\text { Against } \\
\text { Variable }\end{array}$ & $\begin{array}{l}\text { Through } \\
\text { Variables }\end{array}$ & $\begin{array}{c}\text { The } \\
\text { Symbol }\end{array}$ & Result \\
\hline 1. & $\begin{array}{l}\text { Brand Awareness } \\
\text { (X1) }\end{array}$ & $\begin{array}{l}\text { Loyalty } \\
\text { (Y1) }\end{array}$ & $\begin{array}{l}\text { Satisfaction } \\
\text { (Z1) }\end{array}$ & X1Z1Y1 & $\begin{array}{l}0.070 \times 0.302= \\
0.02114\end{array}$ \\
\hline 2. & $\begin{array}{l}\text { Trademark } \\
\text { Association (X2) }\end{array}$ & $\begin{array}{l}\text { Loyalty } \\
\text { (Y1) }\end{array}$ & $\begin{array}{l}\text { Satisfaction } \\
\text { (Z1) }\end{array}$ & $\mathrm{X} 2 \mathrm{Z} 1 \mathrm{Y} 1$ & $\begin{array}{l}0.204 \times 0.302= \\
0.06161\end{array}$ \\
\hline 3. & $\begin{array}{l}\text { Perception of } \\
\text { Quality (X3) }\end{array}$ & $\begin{array}{l}\text { Loyalty } \\
\text { (Y1) }\end{array}$ & $\begin{array}{l}\text { Satisfaction } \\
\text { (Z1) }\end{array}$ & X3Z1Y1 & $\begin{array}{l}0.526 \times 0.302= \\
0.15885\end{array}$ \\
\hline
\end{tabular}

Source: Questionnaire Results Data Processing with SPSS, 2019

Table 8. Test Results Effect of Total (Total Effect)

\begin{tabular}{|c|l|c|c|c|c|}
\hline No. & \multicolumn{1}{|c|}{$\begin{array}{c}\text { Variables } \\
\text { Influence }\end{array}$} & $\begin{array}{c}\text { Against } \\
\text { Variable }\end{array}$ & $\begin{array}{c}\text { Through } \\
\text { Variables }\end{array}$ & $\begin{array}{c}\text { The } \\
\text { Symbol }\end{array}$ & Result \\
\hline 1. & $\begin{array}{l}\text { Brand Awareness } \\
(\mathrm{X} 1)\end{array}$ & $\begin{array}{c}\text { Loyalty } \\
(\mathrm{Y} 1)\end{array}$ & $\begin{array}{c}\text { Satisfaction } \\
(\mathrm{Z} 1)\end{array}$ & $\mathrm{X} 1 \mathrm{Z} 1 \mathrm{Y} 1$ & $\begin{array}{l}0.070+0.302= \\
0.372\end{array}$ \\
\hline 2. & $\begin{array}{l}\text { Trademark } \\
\text { Association }(\mathrm{X} 2)\end{array}$ & $\begin{array}{c}\text { Loyalty } \\
(\mathrm{Y} 1)\end{array}$ & $\begin{array}{c}\text { Satisfaction } \\
(\mathrm{Z} 1)\end{array}$ & $\mathrm{X} 2 \mathrm{Z} 1 \mathrm{Y} 1$ & $\begin{array}{l}0.204+0.302= \\
0.506\end{array}$ \\
\hline 3. & $\begin{array}{l}\text { Perception of } \\
\text { Quality (X3) }\end{array}$ & $\begin{array}{c}\text { Loyalty } \\
(\mathrm{Y} 1)\end{array}$ & $\begin{array}{c}\text { Satisfaction } \\
(\mathrm{Z} 1)\end{array}$ & $\mathrm{X} 3 \mathrm{Z} 1 \mathrm{Y} 1$ & $\begin{array}{l}0.526+0.302= \\
0.828\end{array}$ \\
\hline 4. & Satisfaction (Z1) & $\begin{array}{c}\text { Loyalty } \\
\text { (Y1) }\end{array}$ & - & $\mathrm{Z} 1 \mathrm{Y} 1$ & 0,302 \\
\hline
\end{tabular}

Source of data: Questionnaire Results Data Processing with SPSS, 2019 
This discussion relates to the results of testing the first hypothesis stating that there are significant dimensions of brand equity consisting of brand awareness, brand association and perception partially significant quality to customer satisfaction glorious in Lumajang banana chips. The results showed that the significant effect on customer satisfaction is the association of the brand and perception of quality. While brand awareness has no effect on customer satisfaction. These test results are consistent with Nur Ida Iriani (2011), and Philander Varian Massie (2013) in terms of brand equity dimension variables that affect customer satisfaction research findings on the association of brand and quality perception is partially an effect on satisfaction. While the research results Devolita Agusli and John Sondra Kunto (2013), Cynthia Ratna Ella Cahyadi Santoso and Tabitha (2014) and Pornnarat (2014) these results contradict in terms of brand awareness variable in their research influence on satisfaction. Based on the above, the first hypothesis testing is acceptable for two (2) significant variables that influence the association of the brand and perception of quality, while one (1) other variables that brand awareness does not significantly influence customer satisfaction. Brand awareness is the ability of potential customers to recognize or remember that a brand belonging to the particular product category, so the respondents agreed that: (1) the relevance of the product category, (2) Benefit or functional attributes, (3) Credibility, (4) The values organisatories, (5) The benefits of brand personality on superior products glorious banana chips which is a measure of brand association, that's what makes them feel satisfied after consuming the products featured in the grand Lumajang banana chips. While the size of the perceived quality of the respondents agreed that (1) Services, (2) reliability, (3) Features (4) performance, (5) specification, (6) the economic value and (7) the quality of the final look, that's what makes them satisfied after consuming the products featured in the grand Lumajang banana chips.

Why brand awareness in this study no significant effect on customer satisfaction and different from the results of previous studies? Respondents agreed that: (1) ignorance of the brand, (2) Branding, (3) Brand recall and (4) the brand name first emerged, it was not a factor that makes customers feel satisfied with the great banana chips products. This can be explained because despite the great banana chips is an excellent product in Lumajang single, but many manufacturers are producing the great banana chips with a variety of different brands. The diversity of the great producers in Lumajang banana chips with a variety of different brands and quality that makes the customer difficulty determining what makes this brand they feel satisfied after consuming the great banana chips. So should anyone manufacturers are producing chips grand posing should be able to maintain the quality of the product so that anyone that great banana chips products manufactured be able to give satisfaction to the customer. Furthermore, brand association and perception of quality turns a significant effect on customer satisfaction in Lumajang banana chips sublime. The brand association is everything plugged in memory customers about a brand. While the perception of quality is customer perception of quality or excellence of a product or service in connection with the desired goal, respondents agreed that (1) the relevance of the product, (2) the benefits or functional attributes, (3) the credibility of the product, (4) the values of prestige products, (5) the benefits of the brand personality, (6) services, (7) reliability, ( 8) features, (9) the performance of the products, (10) the specification of products, (11) the economic value and (12) the quality of the final appearance of this great banana chips can give satisfaction to them. So although the great banana chips consumed a variety of different industries or manufacturers home the quality of taste and name of banana chips are made from noble enough to give satisfaction to them.

This discussion relates to the test results of the second hypothesis which states that there are significant dimensions of brand equity consisting of brand awareness, brand association and perceived quality simultaneously significant effect on customer satisfaction in Lumajang banana chips sublime. The results showed that the dimension of brand equity consisting of brand awareness, brand association and perception simultaneously significant quality to customer satisfaction glorious in Lumajang banana chips. These test results are consistent with Nur Ida Iriani (2011) and Philander Varian Massie (2013), Devolita Agusli and John Sondra Kunto (2013), Cynthia Ratna Santoso and Tabita Ella Cahyadi (2014) and Pornnarat (2014) that simultaneous 
dimensions of brand equity effect on satisfaction, So although partial awareness of your brand but it has no effect if combined with the brand association and then three take effect perception quality to customer satisfaction. This shows that despite the different name brands of banana chips manufacturer grand diverse but the products are made from raw banana chips, grand prestige alone is sufficient to provide for consumers. Because it is the great banana is an excellent product that became an icon of Lumajang district in which case super shape is very different from other types of bananas.

This discussion relates to the test results of the third hypothesis stating that there are significant dimensions of brand equity consisting of brand awareness, brand association and perception of significant-quality partially to the great customer loyalty in Lumajang banana chips. The results showed that the dimension of brand equity consisting of brand awareness, brand association and perception of significant-quality effect partially towards customer satisfaction glorious in Lumajang banana chips. These test results are consistent with Nur Ida Iriani (2011) and Philander Varian Massie (2013), Devolita Agusli and John Sondra Kunto (2013), Cynthia Ratna Santoso and Tabita Ella Cahyadi (2014) and Pornnarat (2014) that the partial dimensions of brand equity consisting of brand awareness, brand associations and perceived quality influence on loyalty. Brands owned by the company will be stronger if it has too strong brand equity. Strong brand equity will provide value both to customers and to the company that can provide benefits include: (1) improve the interpretation of the process of receiving customer information, (2) increase customer confidence in purchasing decisions, (3) increase their satisfaction in using the product or services. Strong brand equity will lead to a sense of comfort, increase confidence in the use of, and ultimately create customer satisfaction.

This discussion relates to the test results of the fourth hypothesis which states that there are significant dimensions of brand equity consisting of brand awareness, brand association and perception of significant-quality simultaneously to the great customer loyalty in Lumajang banana chips. The results showed that the dimension of brand equity consisting of brand awareness, brand association and perceived quality simultaneously significant effect on customer satisfaction in Lumajang banana chips sublime. This can occur because of partial brand awareness, brand association and perception of quality has been a significant influence on customer loyalty majestic in Lumajang banana chips. So simultaneous dimensions of brand equity effect on loyalty. Combined, they were able to establish customer loyalty majestic in Lumajang banana chips. What stands out is actual because these chips made from the banana sublime, which is the leading commodity in Lumajang district so as to create pride and prestige for consumers and society Lumajang.

This discussion relates to the test results of the fifth hypothesis states that there is a significant effect of satisfaction on customer loyalty majestic in Lumajang banana chips. The results showed that satisfaction significantly influences customer loyalty majestic in Lumajang banana chips. Satisfaction is a feeling of satisfaction, joy and relief a person because of consuming a product or service to get the service of service. Complacency can be measured by (1)no complaints or complaints are resolved, (2) a feeling of satisfaction of customers on the overall product, (3) compliance with the expectation/expectations of customers and (4) the customer's expectations are exceeded. Sense of satisfaction of customers in Lumajang banana chips grand respondents in this study are met so as to create customer loyalty. Customer loyalty is the great banana chips is reflected on the customer commitment to the brand of chips made from banana supreme, stores or suppliers based on a very positive attitude and is reflected in the consistent purchase.

This discussion relates to the test results of the sixth hypothesis which states that satisfaction may be pemediasi influence the dimension of brand equity consisting of brand awareness, brand association and perceived quality significantly to the great customer loyalty in Lumajang banana chips. The results showed that satisfaction bias to pemediasi on the influence of the dimensions of brand equity consisting of brand awareness, brand association and perceived quality significantly 
to the great customer loyalty in Lumajang banana chips. Strong brand equity will lead to a sense of comfort, increase confidence in the use of, and ultimately create customer satisfaction, which can: (1) improve the efficiency and effectiveness of the company's marketing programs, (2) improve brand loyalty, (3) increase the price/profit margins, (4) increase brand extensions, (5) increase the leverage of trade and (6) increased competitive advantage. So in principle, if the dimensions of brand equity consisting of brand awareness, brand association and perception of quality are able to create a sense of satisfaction for consumers will be able to create customer loyalty which is a measure of consumer loyalty to the brand that has been embedded in her mind that bias is measured by (1 )customers make repeat purchases on a regular basis, (2) the customer purchase other products in the same place, (3) the customer will refer to others, and (4) the customer can not be influenced competitors to move. Products that already gain the loyalty of its customers will be very lucky because it indirectly to keep the existence of the product in the hearts of customers and is able to disseminate information to attract more consumer interest.

\section{CONCLUSION}

Based on the results of research and discussion that has been described above, it can be some conclusions as follows: Dimensions of Brand Equity consisting of brand association and perception of quality significant effect partially to the satisfaction of its customer's excellent products banana chips grand in Lumajang, while brand awareness has no effect significantly to customer satisfaction superior products glorious in Lumajang banana chips. Dimensions of Brand Equity consisting of brand associations and perceived quality simultaneously significant effect on customer satisfaction superior products glorious in Lumajang banana chips.

Dimensions of Brand Equity consisting of brand associations and perceived quality, is a partially significant effect on customer loyalty superior products glorious in Lumajang banana chips. Dimensions of Brand Equity consisting of brand associations and perceived quality simultaneously significant effect on customer loyalty superior products glorious in Lumajang banana chips. Satisfaction significant effect on customer loyalty superior products glorious in Lumajang banana chips. Satisfaction can be a mediator on the influence of the dimensions of brand equity consisting of brand associations and perceived quality of a significant effect on customer loyalty superior products glorious in Lumajang banana chips

Given advice to several parties as follows for Manufacturers Banana chips Court in Lumajang, Contribution of thought in science to producers of banana chips grand in Lumajang that the public or consumers, banana chips sublime love banana chips exalted because the material is an excellent product commodity Lumajang who have a taste special. So although different manufacturers are expected Meek keep the quality of the great banana chips both in terms of taste, appearance and price. Limitations of this study are the study sample is limited only to the superior products glorious in Lumajang banana chips, whereas the leading commodity in Lumajang besides the great banana types there are also other types of well-known banana is a banana ray. It is, therefore, advisable for the next researcher to conduct research with the object of more extensive research. Given the sample of respondents surveyed have a character that is not the same, it will be very interesting if further research is done on other leading products in addition to the great banana chips.

\section{REFERENCE}

Aaker, D. (2013). Aaker On Branding. PT Gramedia Pustaka Utama: Jakarta.

Agusli, D. dan Yohanes, S. K. (2013). Analisa Dimensi Ekuitas Merek Terhadap Minat Beli Konsumen Midtown Hotel Surabaya. Jurnal Manajemen Pemasaran Petra. (Online). Vol.1, No. 2:1-8. (http://studentjournal.petra.ac.id). Diakses 27 Februari 2017. 
Iriani, N. I. (2011). Pengaruh Dimensi Brand Equity (Ekuitas Merek) Terhadap Keputusan Pembelian Kartu Seluler Telkomsel di Kota Malang. Jurnal Aplikasi Manajemen. (Online). Vol.9, No: 2. (http://jurnaljam.ub.ac.id). Diakses 17 Februari 2017

Kartajaya, H. (2010). Brand Operation. Erlangga Group: Jakarta.

Kotler, P. dan Kevin, L. K. (2009). Manajemen Pemasaran. Erlangga: Jakarta.

Kuncoro, M. (2007). Metode Kuantitatif Teori dan Aplikasi Untuk Bisnis dan Ekonomi. UPP STIM YKPN: Yogyakarta.

Massie, P. V. (2013). Ekuitas Merek Pengaruhnya Terhadap Keputusan Pembelian XL Data Service Di Kota Manado. Jurnal EMBA. (Online). Vol.1, No. 4:1474-1481. (http://ejournal.unsrat.ac.id). Diakses 12 Februari 2017.

Nugroho, Y. A. (2011). Its Easy Olah Data Dengan SPSS. Skripta: Yogyakarta.

Pornnarat. B. et al. (2014). Brand Equity Affecting Purchasing Decision Process Of Doughnut From The Departement Store In Bangkok. Prosiding Tahunan Tokyo Bisnis Penelitian Conference (Online). (www.wbiwordconpro.com). Diakses 27 Februari 2017

Santoso. C. R. dan Ella, C. (2014). Analyzing The Impact Of Brand Equity Toward Purchase Intentention In Outomotive Industry : A Case Study Of Abc In Surabaya. iBuss Management. (Online). Vol.2, No.2:29-39. (http://studentjournal.petra.ac.id). Diakses 19 Februari 2017.

Sugiyono. (2009). Metode Penelitian Bisnis. CV Alfabeta: Bandung.

Tandjung, J. W. (2004). Marketing Management Pendekatan Pada Nilai-Nilai Pelanggan. Bayumedia Publishing: Malang.

Tjiptono. F. (2005). Brand Management and Strategy. Andi Publisher: Yogyakarta. 